\title{
Restauración-función en la cultura de masas: crítica a Luz renaciente. Imágenes restauradas
}

\author{
Elsa Arroyo Lemus
}

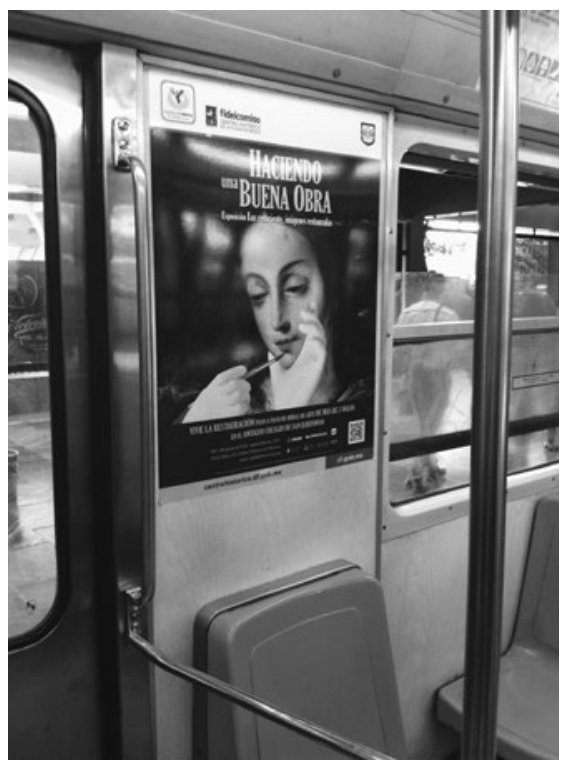

FIGURA 1. El cartel de la exposición en el interior de un vagón de la línea 3 del Metro de la ciudad de México (Fotografía: Elsa Arroyo Lemus, 2013).

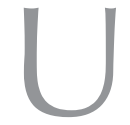

n domingo entre agosto y septiembre, 3:30 de la tarde, Antiguo Colegio de San Ildefonso, Centro Histórico de la ciudad de México. Es época de lluvias y, empotrados en el muro, dos ventiladores giran sin cesar, pero el calor alcanza $25^{\circ} \mathrm{C}$ dentro y fuera de la sala 18. La humedad relativa está entre $75 \%$ y $79 \%$, dependiendo de la colocación del data logger. Los restauradores degustan su lunch en la frescura del corredor aéreo, al otro lado del edificio, seguramente a propósito alejados de los vapores orgánicos que exhalan los frascos de disolventes destapados o el algodón usado en los hisopos acumulados durante la mañana o los ya inocuos, olvidados al aire libre quizá desde el día anterior.

Aunque me resultan familiares, tanto el olor a gasolina blanca y a xileno, como la presencia de caballetes, planchas de reentelado, aspiradoras, bastidores de trabajo y escalpelos, este espacio me intriga desde el principio como espectadora, visitante ocasional y restauradora curiosa. Y es que esa primera sala de la exhibición Luz renaciente. Imágenes restauradas que se inauguró hacia finales de mayo de 2013 en el Antiguo Colegio de San Ildefonso (2013) contiene el "taller" del restauro, lugar donde "renacen" las imágenes virreinales procedentes, según reza el título de la muestra, de diversos fondos eclesiásticos del norte del país.

Hay cámaras que transmiten segundo a segundo, en vivo y en directo, la actividad del "taller"; todos ellos mecanismos que transmiten en imágenes de televisión las acciones que se dan ahí sobre las pinturas. Sin importar que los profesionales y sus objetos de trabajo estén exhibidos frente al visitante, las pantallas desdoblan con más detalle lo que ocurre en tiempo real y, efectivamente, a corta distancia. Ahí, en el televisor sucede el testimonio del "renacimiento", lo que no es extraño si pensamos en un público acostumbrado a conocer y saber el mundo ${ }^{1}$ a través de una pantalla a todo color. El detalle del tratteggio ${ }^{2}-\mathrm{O}$

\footnotetext{
${ }^{1}$ Uso libremente esta frase que hace referencia al título de la obra de Immanuel Wallerstein (2002) a propósito del fin de los sistemas-mundo y la crisis del conocimiento desde las ciencias sociales. ${ }^{2}$ El tratteggio es una técnica de reintegración de lagunas desarrollada en el Istituto Centrale del Restauro en Roma por Paolo y Laura Mora a propósito de la intervención de frescos italianos dañados durante la Segunda Guerra Mundial. Es un método mecánico que consiste en el uso de
} 
rigattino, en el argot de la restauración mexicana—, la limpieza de barniz que abre el paso al color "original", los faltantes de pintura resanados con pasta de cera roja y oscura para borrar el deterioro abierto por el envejecimiento y el daño sobre la policromía parecieran más vívidos en las pantallas. Por eso los televisores separan al espectador del restaurador ejecutante: son la barrera que aísla los dos mundos, el del público en general y el del especialista profesional y científico. Finalmente, un museo requiere el establecimiento de límites en el espacio. Pero la separación no se nota por razón de que, con la transmisión en red, el espectador se descubre más cerca del acaecimiento, del acontecer histórico, "del momento metodológico del reconocimiento de la obra de arte" (Brandi 1989:15) o del proceso en que se devuelve la vida a un paciente moribundo mediante una larga y cuidadosa intervención quirúrgica.

Para aquel que no puede visitar el recinto, hay transmisión por internet. Los celosos secretos del profesional en restauración ya son del dominio público. Dos cámaras en vivo documentan el proceso. Aquí no hay montaje, pues esto no es Restaurando México, ${ }^{3}$ de modo que el documental se genera minuto a minuto como parte del registro legitimador de las intervenciones.

Imposible dejar de reconocer el éxito mediático. En prensa, radio y TV, la propaganda de la Luz renaciente inunda el parabús, el puesto de periódicos —ni los clandestinos se salvan-y los andenes del metro (Figura 1). La exposición funciona como dispositivo para despertar la conciencia del gran público sobre la importancia de la conservación del patrimonio pictórico novohispano de temática religiosa. También cumple su objeto de conseguir patrocinios diversos para devolver las piezas en un estado completo y legible a sus lugares de origen; aquí cuentan desde el peso del paseante enganchado por la mística del antes y después de la intervención hasta el cheque cuantioso de personas y organizaciones convencidas de la bondad de la iniciativa.

Al final, dos cuestiones parecen extrañas a la intención de la muestra. La primera es la vía de comunicación entre un tema especializado y el gran público: parece que la única manera de enseñar, o "culturizar", es a través de una pantalla de televisión. Sobreviene una segunda extrañeza cuando pinturas que colgaban exhibiendo años de degradación material se convierten en obras de arte

delgadas líneas verticales yuxtapuestas, basadas en el principio de la división de tonos, de tal modo que primero se pone el tono base del retoque con líneas de $1 \mathrm{~cm}$ de largo en promedio dispuestas a intervalos que después se rellenan con un segundo y un tercero de colores puros. En su origen fue pensado para ser usado con acuarelas. La técnica se difundió en México después del curso sobre restauración de pintura mural impartido por Laura Mora en 1968 (Mora et al. 1996:343-354; Bailão 2011:51).

${ }^{3}$ Restaurando México fue una serie documental de Canal 22 compuesta por 13 episodios con la que se buscó la difusión de la investigación y conservación del patrimonio cultural de México (Canal 22 2013). por una suerte de "descubrimiento" o al ser "resucitadas" tras la restauración, esto es, la enunciación o declaración de sus valores históricos y estéticos se produce mediante su inserción en un discurso museográfico y, si acaso, en su presentación académica dentro de un catálogo de exposición. En este proceso, los objetos culturales (pinturas y esculturas) mutan de testimonios históricos y artísticos potencialmente útiles dentro de un contexto cultural determinado a materiales excepcionales, completos y listos para afrontar una nueva vida como agentes identitarios o alimentos del conocimiento (Chanfón Olmos 1988:257).

Mientras que sobre las mesas, en los caballetes, o incluso apoyadas en los muros del pasillo exterior del colegio jesuita, las pinturas son cosas de este mundo: telas y pigmentos aglutinados al óleo, bastidores de madera vieja y preparaciones craqueladas, al pasar del taller al museo, es decir, de la sala 18 a la 19, adquieren otro estatus. Ya no importa que hayan estado en condiciones fluctuantes de humedad relativa ni el calor de Chihuahua ni los dedos del restaurador; han cruzado el umbral en que se reconoce una pieza patrimonial y ya es imposible siquiera intentar acercarse a ver las zonas en las que había faltantes de pintura. Ya son obras de arte dentro de un museo. Las jóvenes que custodian el recinto piden un metro de distancia de observación. La cantidad de luxes asignada para la exhibición de pinturas de caballete no ayuda al espectador y el barniz de resina natural hace todo para que la física opere en la superficie del lienzo, desafortunadamente en detrimento de la capacidad de observación del ojo humano. Desde que estos objetos fueron seleccionados para viajar de los sitios en que habían estado exhibidos durante siglos hasta la ciudad de México, ya se había destacado su valor estético, pero no fue sino hasta la restauración cuando llegaron a concebirse como piezas de alto valor cultural. Aquí es donde opera de manera positiva una conocida y capital declaración de la restauración como disciplina: "Tiene como fin conservar y revelar los valores estéticos e históricos del monumento..." (ICOMOS 1964:art. 9). En el espacio del museo, las piezas ya tienen otra utilidad, lejana a la función ritual, litúrgica, social o decorativa que les dio origen.

Los profesionales en restauración - como ellos mismos aclaran en un video al final de la muestra- consiguen que las imágenes de los lienzos renazcan más a la manera de maestros de alquimia que como científicos en el desarrollo de un método interdisciplinario. Aquí la operación quirúrgica llevada a cabo sobre las obras obedece a la repetición de los saberes técnicos y no a preguntas sobre lo que cada pieza requería en materia de conservación; por eso la enorme mampara explicativa en la que se expone de modo didáctico toda la ruta del proceso que conlleva la intervención de una pintura de caballete ocupa la zona central de la primera sala de exhibición. Como si se tratara de una ruta única. Desde que se estudia la licenciatura en restauración se nos enseña que, en su acepción de intervención directa sobre la 
imagen, la restauración debiera ser una acción excepcional, realizada después de que los medios preventivos no fueron suficientes para mantener en buen estado las imágenes (Calvo 1997:193). Pero en Luz renaciente se omite cualquier pregunta sobre el destino final de las pinturas y también sobre su origen. Algunas cédulas en el espacio de la sala donde se presentan las obras ya terminadas ofrecen el análisis iconográfico de la escena, información que se confunde en medio de los esquemas y levantamientos de los deterioros previos. A la mayoría de las piezas se les hizo de todo para "restaurarlas". Destaca lo prolijo y socorrido que sigue siendo el reentelado a la cera resina, así como los barnizados con cera. ${ }^{4}$ Hay que decir que la naturaleza de este tipo de intervenciones es inmediata: se trata de acciones de corta duración. Los barnices de restauración tienen expectativas de vida útil cortas en espacios sin control de humedad y temperatura. El reentelado a la cera resina, por su parte, presenta asimismo, después de 20 o 30 años, las huellas del proceso de planchado, manchas del engrudo del velado que aparecen como telarañas blancas sobre las craqueladuras y, por supuesto, un oscurecimiento notable del color. Incluso la imagen del cartel de Luz renaciente apela a la noción de la restauración como maquillaje: el rostro de la Virgen recibe un retoque cuidadoso con el fin de disimular el envejecimiento. Sin duda está implícita la obsesión del ser humano por mantenerse siempre joven o el miedo a la muerte: Dorian Gray.

Al terminar la visita lo que más se comenta entre el público no especializado es el respeto que infunden la paciencia y la minuciosidad implicadas en la labor del restauro. Para los otros que somos nosotros, restauradores de profesión, involucrados con la pintura, los temas son varios: la mística (o la experiencia con lo divino) alrededor del papel del restaurador, las bajas condiciones de seguridad para los trabajadores y visitantes, así como la evidente carencia de equipamiento de alta tecnología empleado para la restauración en este y en la gran mayoría de los talleres de su tipo en México (equipos para el registro del proceso de restauración y para el diagnóstico del deterioro, zonas específicas para barnizado o preparación de sustancias tóxicas, espacios y equipos para tomas radiográficas, ultravioleta infrarrojo, mesas de succión y control de temperatura, iluminación con luz de día, espacios climatizados y con extracción y purificación de aire, mobiliario con control de temperatura y filtros para almacenamiento de disolventes, sillas o bancos de trabajo - al menos - adecuados para el trabajo continuo frente a obra, caballetes versátiles o motorizados, entre muchos otros). ${ }^{5}$ Para nosotros, digo, son entonces

\footnotetext{
${ }^{4}$ Las referencias bibliográficas con evidencias, discusiones y reflexiones sobre los reentelados a la cera resina son amplísimas; algunas fundamentales son: Staniforth y Bomford (1985); Marvelde (2012); Villers (2003).

${ }^{5}$ La apertura al público de talleres de restauración establecidos en las
}

obligadas ciertas preguntas: qué tan científico e interdisciplinario es el trabajo del conservador-restaurador de bienes culturales; por qué se arman talleres improvisados en las salas de los museos y no se considera como una necesidad permanente el abrir a la vista del público todo proceso de intervención sobre el patrimonio en el país, en especial de los principales museos y recintos patrimoniales mexicanos; por qué no se busca la actualización permanente de los conservadores-restauradores.

Mi último interrogante es sobre la perspectiva en la intervención de pinturas, área por demás clásica en la construcción disciplinar del campo de la conservación: ¿cómo vamos a intervenir las lagunas, la oxidación y las craqueladuras en materia de conservación-restauración si nos presentamos como miembros de un ámbito de alta especialización y prodigio de manos privilegiadas, como lo ejemplifica ampliamente la exhibición en San Ildefonso? En 1999, David Bomford (2003) escribió un artículo donde presentaba un balance del papel del profesional en conservación y el desarrollo del área en la National Gallery (Londres) durante la segunda mitad del siglo Xx. Ahí decía - con el orgullo que produce estar en una situación totalmente distinta- que hubo un tiempo en que su función como asistente en el departamento de restauración consistía sólo en reparar, limpiar y retocar cuadros; en ese periodo los restauradores apenas escribían, no daban conferencias ni opinaban de historia del arte (Bomford 2003:12). Quizá hoy sea momento de pensar qué queremos ser cuando seamos grandes.

\section{Referencias}

\section{Antiguo Colegio de San Ildelfonso}

2013 Luz renaciente. Imágenes restauradas, documento electrónico disponible en [http://www.sanildefonso.org.mx/ expos/luzrenaciente/index.html], consultado el 17 de septiembre del 2013.

Bailão, Ana

2011 "As técnicas de reintegração cromática na pintura: revisão historiográfica", GE Conservación (2): 45-63.

Bomford, David

2003 "The Conservator as Narrator: Changed Perspectives in the Conservation of Paintings", en Mark Leonard (ed.), Personal Viewpoints: Thoughts about Painting Conservation, Los Angeles, The Getty Conservation Institute, 1-12.

salas de los museos no es cosa nueva; basta mencionar el taller abierto en 1994 a propósito del proyecto Vermeer Illuminated en el museo Mauritshuis (La Haya, Países Bajos) (Wadum 1994). Actualmente se restaura El cordero místico, el políptico de los hermanos Van Eyck, en el Museum voor Schone Kunsten (Gante, Bélgica) (Museum voor Schone Kunsten 2014) y también hay un espacio de restauración en el Bonnefantenmuseum de Maastricht (Maastricht, Países Bajos) (Bonnefantenmuseum de Maastricht 2014); vale la pena ver las instalaciones, metodología y técnicas de cada uno de estos casos. 
Bonnefantenmuseum

2014 The Limburg Conservation Institute (SRAL - Stichting Restauratie Atelier Limburg), Maastricht, Bonnefantenmuseum, documento electrónico disponible en [http://www.bonnefanten.nl/en/exhibitions/open_restauration_atelier], consultado en marzo de 2014.

Brandi, Cesare

1989 [1963] Teoría de la restauración, Madrid, Alianza.

Calvo, Ana

1997 Conservación y restauración: materiales, técnicas y procedimientos de la A a la Z, Barcelona, Del Serbal.

Canal 22

2013 Restaurando México; serie documental, México, Producciones Camaleón, documento electrónico disponible en [http://www.conaculta.gob.mx/detalle-nota/?id=19977\#. UjkahLyDbt8], consultado el 17 de septiembre de 2013.

Chanfón Olmos, Carlos

1988 Fundamentos teóricos de la restauración, México, Facultad de Arquitectura-UNAM.

ICOMOS

1964 "Carta Internacional sobre la Conservación y la Restauración de Monumentos y Sitios (Carta de Venecia)", documento electrónico disponible en [http://www.icomos.org/charters/venice_sp.pdf], consultado en septiembre de 2013.

Marvelde, Mireille te

2012 "Wax-resin lining", en Joyce Hill Stoner y Rebecca

\section{Resumen}

Esta es una reseña de la exhibición museográfica $L u z$ renaciente. Imágenes restauradas presentada en el Antiguo Colegio de San Ildefonso de mayo a septiembre de 2013. Aquí se discuten cuestiones sobre la difusión de la restauración y conservación de obras virreinales, así como de los procesos de la intervención de las pinturas, poniendo especial énfasis en analizar la noción disciplinar de la restauración que se hace implícita en la muestra.

\section{Palabras clave}

restauración; arte virreinal; difusión
Rushfield (eds.), Conservation of easel paintings, Nueva York, Routledge, 424-433.

Mora, Paolo, Laura Mora y Paul Philippot

1996 [1975 y 1984] "Problems of presentation", en Nicholas Stanley Price et al. (eds.), Historical and philosophical issues in the conservation of cultural heritage, Los Ángeles, The Getty Conservation Institute, 343-354.

Museum voor Schone Kunsten

2014 "The Ghent Alterpiece", documento electrónico disponible en [http://closertovaneyck.kikirpa.be/\#home], consultado en marzo de 2014.

Staniforth, Sarah y David Bomford,

1985 "Lining and Colour Change: Further Results", National Gallery Technical Bulletin, 9, documento electrónico disponible en [http://www.nationalgallery.org.uk/upload/pdf/staniforth_bomford1985.pdf], conusultado en marzo de 2014.

Villers, Caroline (ed.)

2003 Lining paintings: Papers from the Greenwich Conference on Comparative Lining Techniques, Londres, Archetype.

Wallerstein, Immanuel

2002 Conocer el mundo, saber el mundo: el fin de lo aprendido. Una ciencia social para el siglo XXI, México, Siglo XXI Editores/UNAM.

Wadum, Jorgen

1994 Vermeer Illuminated. Conservation, Restoration and Research, La Haya, Mauritshuis Museum.

\section{Abstract}

This is a review of Luz Renaciente. Imágenes Restauradas (Light reborn. Restored images), a museum exhibition presented in the Antiguo Colegio de San Ildefonso from May to September, 2013. The critique discusses issues both about the dissemination of conservation-restoration of works of art from the Viceregal period as well as regarding the processes involved in restoring easel paintings, in order to emphasize the analysis of the disciplinary notion of restoration that was implicit in the exhibition.

\section{Key words}

restoration; viceregal works of art; dissemination

Titulo en Inglés: Restoration's function in mass culture: a critique to Luz Rena-

ciente. Imágenes Restauradas (Light reborn. Restored images)

Postulado/Submitted 20.09.2013

Aceptado/Accepted 4.02.2014 